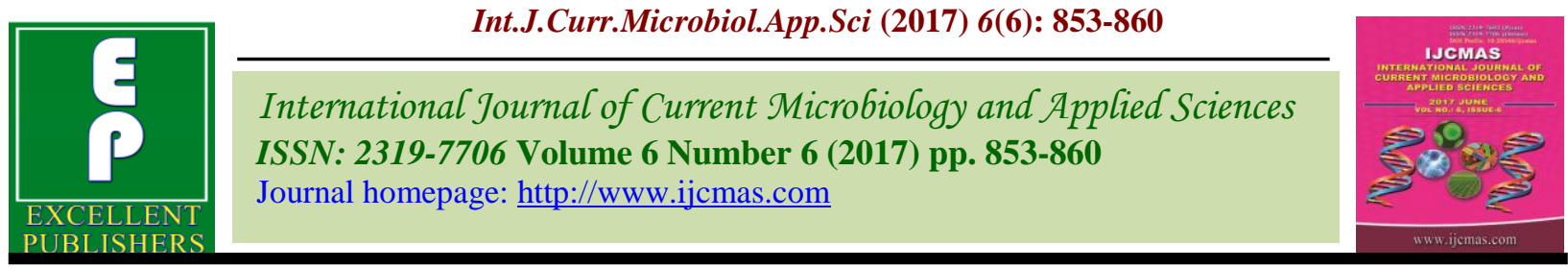

Original Research Article

https://doi.org/10.20546/ijcmas.2017.606.100

\title{
Isolation and Characterization of Protease Producing Bacillus Species from Soil of Dairy Industry
}

\author{
R.C. Patil ${ }^{1,2 *}$ and B.L. Jadhav ${ }^{2}$ \\ ${ }^{1}$ Department of Microbiology Bhavan's College, Andheri, Mumbai, India \\ ${ }^{2}$ Department of Life Sciences, University of Mumbai, Mumbai, India \\ *Corresponding author
}

\section{A B S T R A C T}

Proteases have a long history of application in food and detergent industries. The attempt of this study was to isolate the protease enzyme producing Bacillus species from various dairy industries. In the present study 25 soil samples were collected from various dairy

\begin{tabular}{l} 
Ke y w or d s \\
Protease enzyme, \\
Bacillus species, \\
$\begin{array}{l}\text { Dairy industry, } \\
\text { Soil. }\end{array}$ \\
\hline Article Info \\
\hline $\begin{array}{l}\text { Accepted: } \\
17 \text { May } 2017 \\
\text { Available Online: } \\
\text { 10 June } 2017\end{array}$ \\
\hline
\end{tabular}
industry and proceed for isolation and identification of protease producing bacteria specially Bacillus spp. In the present study a total of 28 Bacillus species were isolated which includes Bacillus subtilis was predominantly found which were $8(28 \%)$ followed by Bacillus megaterium 7 (25\%), Bacillus cereus 5 (18\%), Bacillus licheniformis 5 (18\%) and Bacillus brevis 3 (11\%). Among the 28 Bacillus species 3 isolates such as SP3 (Bacillus cereus), SP10 (Bacillus licheniformis) and SP21 (Bacillus megaterium) showed significant protease enzyme production after $24 \mathrm{~h}$. SP3 showed excellent protease production after $72 \mathrm{~h}$ followed by SP10 and SP21 which was $35 \mathrm{~mm}, 26 \mathrm{~mm}$ and $18 \mathrm{~mm}$ respectively. The protease enzyme from Bacillus SP3 was partially purified by ammonium sulfate fractionation. The specific activity of crude protease enzyme was $7.71 \mathrm{U} / \mathrm{mg}$ of protein. The specific activity of ammonium sulfate fractionation is found to be 10.32 and the fractionation is 1.32 fold purified from the crude enzyme preparation yielding $75.75 \%$ from the crude protein. The optimum $\mathrm{pH}$ of protease produced from Bacillus cereus (SP3) shown at the $\mathrm{pH}$ 7.0. The purified enzyme was loaded onto holes punched on skim milk agar. After 24-48 hours of incubation it was observed that clear zones were formed successfully. It can be produced in large scale for the potential industrial applications.

\section{Introduction}

Microbial enzymes are often more useful than enzymes derived from plants or animals because of are more stable than their corresponding plant and animal enzymes and their production is more convenient and safer (Wiseman, 1987). Only about $2 \%$ of the world's microorganisms have been tested as enzyme sources. Microbial proteases are degradative enzymes, which catalyze the total hydrolysis of proteins (Raju et al., 1994; Haq et al., 2006).
Proteolytic enzymes are ubiquitous in occurrence, being found in all living organisms, and are essential for cell growth and differentiation. The extracellular proteases are commercial value and find multiple applications in various industrial sectors. Although there are many microbial sources available for producing proteases, only a few are recognized as commercial producers (Gupta et al., 2004). Of these, strains of Bacillus sp. dominate the industrial 
sector (Gupta et al., 2002). Several species of strains bacteria (Bacillus licheniformis, $B$. firmus, B. alcalophilus, B.amyloliquefaciens, $B$. proteolyticus, B. subtilis, B. thuringiensis B. cereus, B. sterothermophilus, $B$. mojavensis and B. megaterium) are reported to produce proteases (Beg et al., 2003, Banik et al., 2004, Gerze et al., 2005, Soares et al., 2005). Proteases are one of the most important groups of industrial enzymes and account for nearly $60 \%$ of the total enzyme sale (Brown and Yada, 1991 and Escobar and Barnett, 1993).

The major uses of free proteases occur in the food, dairy, pharmaceutical, textile industries dry cleaning, detergents, meat processing, cheese making, silver recovery from photographic film, production of digestive and certain medical treatments of inflammation and virulent wounds and are produced in large amounts by microbial synthesis (Nout and Rombouts, 1990; Aleksieva and Peeva, 2000). Protease treatments can modify the surface of wool and silk fibers to provide new and unique finishes. Proteases have been used in the hide dehairing process, where dehairing is carried out at $\mathrm{pH}$ values between 8 and 10 (Ishikawa et al., 1993). Proteases are also useful and important components in biopharmaceutical products such as contact-lens enzyme cleaners and enzymatic deriders (Anwar et al., 2000). The proteolytic enzymes also offer a gentle and selective debridement, supporting the natural healing process in the successful local management of skin ulcerations by the efficient removal of the necrotic material (Sjodahl et al., 2002). Protease is also used for the deproteination of marine crustacean wastes. Approximately $60 \%$ of the enzymes used commercially are proteases (Badgujar and Mahajan, 2010).

Proteases are broadly classified as endo or exoenzymes on the basis of their site of action on protein substrates. They are further categorized as serine protease, aspartic proteases, cysteine proteases, or metalloproteases depending on their catalytic mechanism (Geethanjali and Subash, 2011). Alkaline serine proteases of microbial origin possess considerable industrial potential due to their biochemical diversity and wide applications in tannery and food industries, medicinal formulations, detergents and processes like waste treatment, silver recovery and resolution of amino acid mixtures (Salem et al., 2009).

The demand for industrial enzymes, particularly microbial origin, is ever increasing owing to their applications in a wide variety of processes (Padmapriya et al., 2012).

\section{Materials and Methods}

\section{Collection of samples}

For the isolation of the protease producing bacteria a total of twenty five soil samples were collected from different dairy industries of Aurangabad city (MS) India. The soil samples were collected in sterile plastic bags and immediately carried to the research centre, Aurangabad, (MS) India for further studies.

\section{Isolation of the microorganisms}

The primary screening was done by the skimmed agar plate method. The soil sample $(1 \mathrm{gm})$ was diluted in $100 \mathrm{ml}$ of sterilized distilled water and heated at $80^{\circ} \mathrm{C}$ for 15 minutes. The skimmed milk agar plate was inoculated by the spread plate method with $0.1 \mathrm{ml}$ of heated diluted soil sample and incubated aerobically at $37^{\circ} \mathrm{C}$. Heat treatment to the dilution was killed all the vegetative cells and remain only spores of Bacillus species. Strains that were capable of producing protease enzymes were screened by 
allowing them to grow for $24 \mathrm{hr}$ on skimmed milk agar plate at $37^{\circ} \mathrm{C}$. The plates were observed for zone of hydrolysis for protease production and were chosen for further investigation.

\section{Identification of enzyme producers}

Protease producer was identified on the skimmed milk agar by observing the zone of hydrolysis around the colony or growth. After identification of enzyme producer each colony was then isolated by streaking on the slants of nutrient agar. Then these slants were incubated at $37^{\circ} \mathrm{C}$ for $24-48 \mathrm{hrs}$ and further proceed for identification of strains. Identification of bacterial strains was done on the basis of standard morphological, biochemical, and sugar fermentation test.

\section{Production and extraction of protease enzyme}

A $500 \mathrm{ml}$ of Skimmed milk broth was prepared according to the composition in the $1000 \mathrm{ml}$ of conical flask. All components were dissolved in the distilled water. The conical flasks containing medium were autoclaved at $121^{\circ} \mathrm{C}$ for $15 \mathrm{~min}$ at $15 \mathrm{LBS}$ pressure. After the isolation and screening of protease producing microorganism, efficient protease producer microorganism was inoculated in $500 \mathrm{ml}$ of three broths and it was then incubated in shaking water bath at $37^{\circ} \mathrm{C}$ for $72 \mathrm{hrs}$. It was observed daily for the growth in the flasks up to complete incubation period. After 3 days of incubation, content of flasks was centrifuged at $10000 \mathrm{rpm}$ for 10 mins at $4^{\circ} \mathrm{C}$. A clear supernatant was recovered after centrifugation. The crude enzyme supernatant was tested for the protein determination by Biuret test, protease assay (i.e. Folin-Lowry method). This isolated crude enzyme was processed for its purification by salting-out method using $\left(\mathrm{NH}_{4}\right)_{2} \mathrm{SO}_{4}$, an ammonium sulfate a neutral salt.

\section{Partial purification by salting-out method}

First of all, the volume of 3 crude enzymes were measured and then it was treated with $50 \%\left(\mathrm{NH}_{4}\right)_{2} \mathrm{SO}_{4}$. The salt was slowly added to the volume of crude enzymes with continuous stirring, after completing the addition, the enzyme was kept at $4^{\circ} \mathrm{C}$ overnight precipitation. Next day, the enzyme was brought to room temperature and then proceeds for the centrifugation to separate the protein precipitated from the rest of the liquid. The precipitate was containing fractionated enzyme (protease) and supernatant contained other soluble proteins. Then both precipitate and supernatant were assayed for the enzyme activity by using protease assay. The supernatant was showing enzyme activity, thus it proceeded for further precipitation with the same salt with high concentration as $60 \%$.

The process was continued till supernatant would not show any enzyme activity. Thus it was precipitated till $90 \%$ of $\left(\mathrm{NH}_{4}\right)_{2} \mathrm{SO}_{4}$ salt concentration. The protein/enzyme was resuspended in $0.1 \mathrm{M}$ Phosphate buffer, $\mathrm{pH}$ 7.0, and dialyzed against the same buffer.

\section{Biuret test}

Standard protein solution (BSA) was pipetted out into a series of tubes $-0.1,0.2, \ldots, 1 \mathrm{~mL}$ from stock solution of $100 \mathrm{mg} / \mathrm{ml} .3 \mathrm{ml}$ of biuret reagent was added in all different concentration tubes. These tubes were incubated at $37^{\circ} \mathrm{C}$ for 10 minutes.

Then $2 \mathrm{ml}$ of distilled water was added to each tube except in blank to make up the volume $6 \mathrm{ml}$. The optical density for each tube was taken at $530 \mathrm{~nm}$ on UV-VIS Spectrophotometer. Then graph was drawn of Concentration of Standard protein against the respective O.D. at $530 \mathrm{~nm}$. Same procedure was followed for the protein estimation of unknown sample. 


\section{Protease assay}

One ml of enzyme was added in a tube containing $1 \mathrm{ml}$ of buffer and $1 \mathrm{ml}$ of substrate. A 5 reaction mixture were prepared with different $\mathrm{pH}$ buffer $(7,8,9,10,11)$. Above reaction mixtures was incubated at $37^{\circ} \mathrm{C}$ for 20 minutes. After $20 \mathrm{~min}$ of incubation reaction was terminated by adding $1 \mathrm{ml}$ of TCA in it. Blank was prepared by using distilled water in place of the casein substrate. Above terminated reaction mixture was filtered using filter paper. Filtrates prepared at different $\mathrm{pH}$ were tested for the Folin Lowry method of protein estimation. Highest enzyme activity was observed at optimized $\mathrm{pH}$ and noted down.

\section{Folin Lowry method}

Standard protein solution (BSA) was pipetted out into a series of tubes $-0.1,0.2, \ldots, 1 \mathrm{~mL}$ from stock solution of $200 \mathrm{mg} / \mathrm{ml}$. A $5 \mathrm{ml}$ of alkaline solution was added in each tube and allowed to stand for 10 minutes at room temperature. $0.5 \mathrm{ml}$ of diluted $\mathrm{F}-\mathrm{C}$ reagent was added with immediate mixing. Above reaction mixture was kept at room temperature for 30 mins. After 30 minutes, O.D. was taken at $750 \mathrm{~nm}$ on UV-VIS Spectrophotometer. Then graph was drawn of Concentration of Standard protein against the respective O.D. at $750 \mathrm{~nm}$. Same procedure was followed for the protein estimation of unknown sample.

\section{Isolated efficient protease producer identified by sequenced}

The morphological characteristics of the isolates were identified by Gram staining and biochemical reactions (Balow et al., 1992). The biochemical reactions included glucose fermentation, catalase and oxidase production. Confirmation was done by $16 \mathrm{~S}$ rRNA sequencing from NCCS, University of
Pune. These isolates were initially identified by Ribosomal Database Project (RDP). Sequences obtained through RDP were subjected to Basic Local Alignment Search Tool (BLAST) to obtain significant relationships from chance similarities.

\section{Results and Discussion}

In the present study, a total of 25 soil samples were collected from dairy industry in sterilized polythene bag. From the 25 soil samples, 28 Bacillus species were isolated and identified on the basis of morphological and biochemical characteristics as well as screened for protease enzyme production activity. All the isolates were found gram positive rods, motile and spore forming. Isolates were produced hydrolytic enzymes such as gelatinase, catalase and amylase. They fermented sugars without production of gases and reduced nitrates to nitrites. Isolates SP1, SP5, SP9 SP11, SP16, SP20, SP25 and SP28 were identified as Bacillus subtilis whereas isolates SP3, SP6, SP8, SP18 and SP22 were identified as Bacillus cereus. Isolates SP2, SP12, SP14, SP17, SP21, SP23 and SP27 were identified as Bacillus megaterium whereas SP4, SP24 and SP26 were identified as Bacillus brevis and isolates SP7, SP10, SP13, SP15 and SP19 were identified as Bacillus licheniformis. Few moderate alkaliphilic strains especially representatives of the genus Bacillus, are able to produce extracellular amylase, lipase and proteases that are even active at alkaline $\mathrm{pH}$ (Martins et al., 2001; Vargas et al., 2004; Tambekar and Tambekar, 2012). A large number of alkaliphilic Bacillus strains have been isolated for industrial applications (Horikoshi, 1971).

From the (Fig. 1) it was observed that among the 28 Bacillus species, Bacillus subtilis was predominantly found which were $8(28 \%)$ followed by Bacillus megaterium 7 (25\%), 
Bacillus cereus 5 (18\%), Bacillus licheniformis 5 (18\%) and Bacillus brevis 3 $(11 \%)$. After the isolation and identification, isolated Bacillus species were used for screening of protease enzyme. Among the 28 Bacillus species 3 isolates such as SP3 (Bacillus cereus), SP10 (Bacillus licheniformis) and SP21 (Bacillus megaterium) showed significant protese enzyme production after $24 \mathrm{~h}$, hence these isolates were incubated different time intervals $(24 \mathrm{~h}, 48 \mathrm{~h}$ and $72 \mathrm{~h}$ ) to observe the maximum protease production. From the (Fig. 2), SP3 showed $15 \mathrm{~mm}$, SP10 showed $18 \mathrm{~mm}$ and SP21 showed 9mm of casein hydrolysis after $24 \mathrm{~h}$ while after $48 \mathrm{~h}$ they showed $30 \mathrm{~mm}$, $22 \mathrm{~mm}$ and $14 \mathrm{~mm}$ respectively. SP3 showed significant protease production after $72 \mathrm{~h}$ followed by SP10 and SP21 which was $35 \mathrm{~mm}, 26 \mathrm{~mm}$ and $18 \mathrm{~mm}$ respectively.

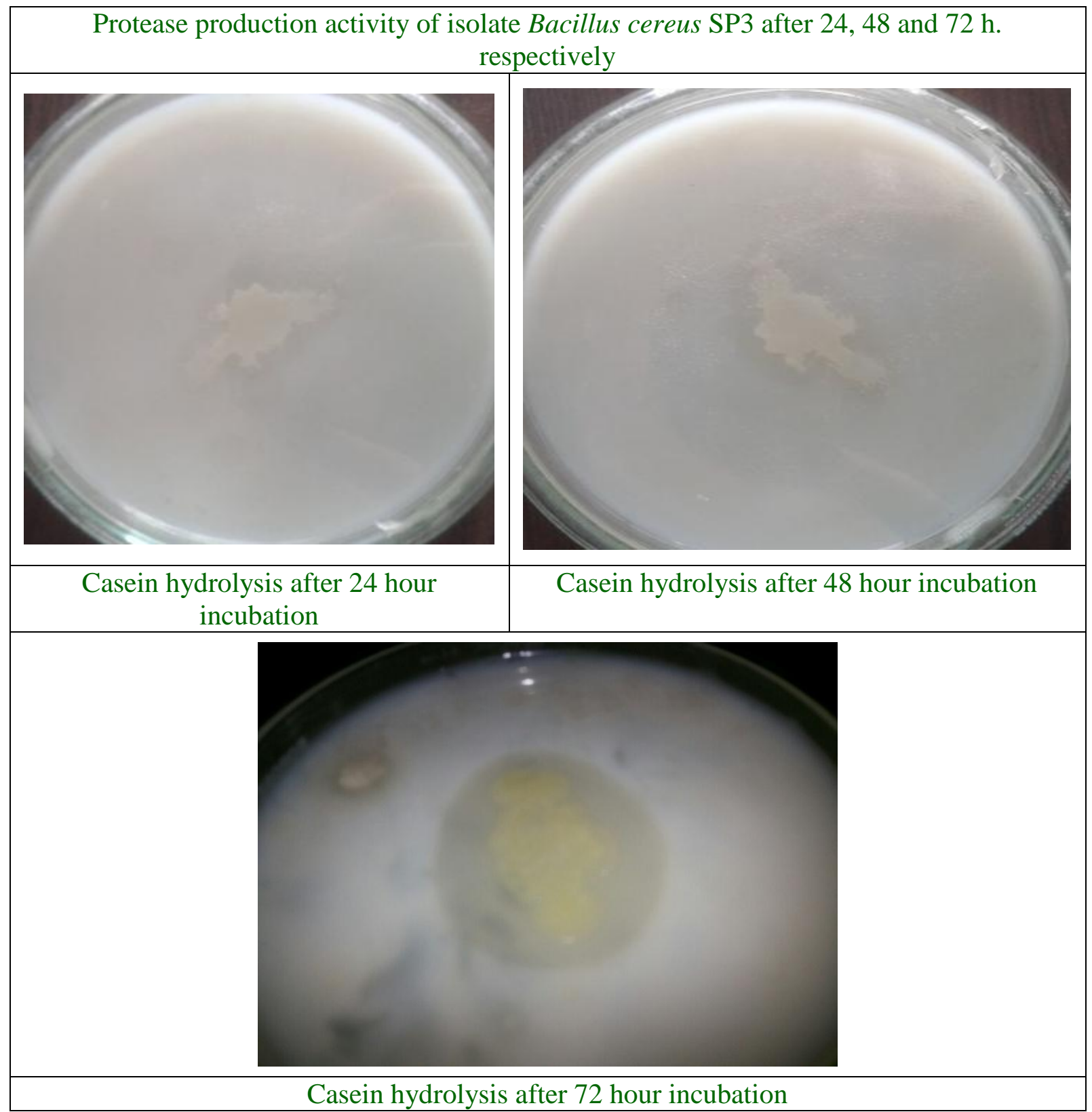




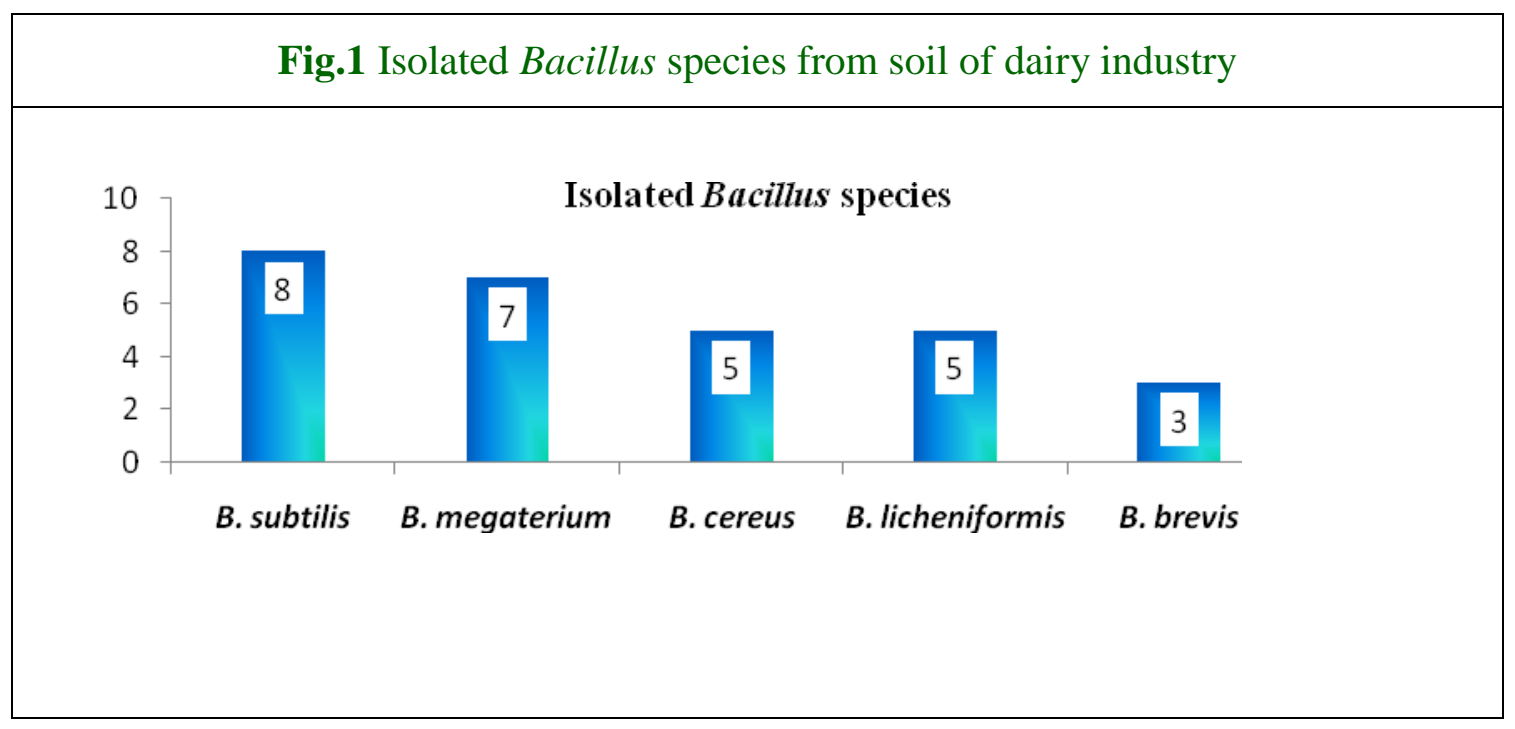

Fig.2 Zone of casein hydrolysis (mm) of isolated Bacillus species from soil of dairy industry after $24 \mathrm{~h}, 48 \mathrm{~h}$ and $72 \mathrm{~h}$

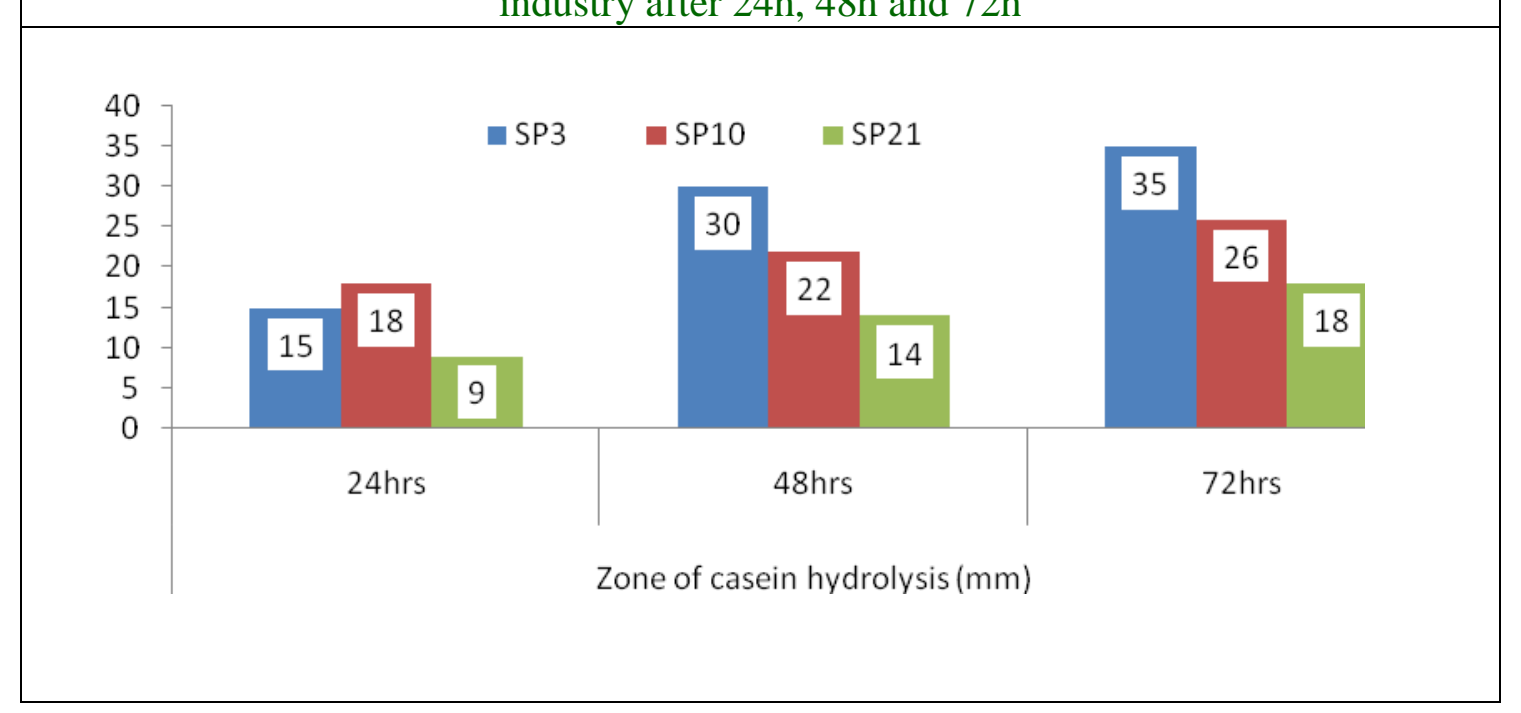

\begin{tabular}{|l|l|l|l|l|l|}
\hline $\begin{array}{l}\text { Purification } \\
\text { Step }\end{array}$ & $\begin{array}{l}\text { Total } \\
\text { Enzyme } \\
\text { Activity (U) }\end{array}$ & $\begin{array}{l}\text { Total } \\
\text { Protein (mg) }\end{array}$ & $\begin{array}{l}\text { Specific } \\
\text { Activity } \\
\text { (U/mg) }\end{array}$ & $\begin{array}{l}\text { Purification } \\
\text { Fold }\end{array}$ & $\begin{array}{l}\text { \% } \\
\text { Recovery }\end{array}$ \\
\hline $\begin{array}{l}\text { Crude } \\
\text { enzyme }\end{array}$ & 30210 & 3920 & 7.71 & 1.0 & 100 \\
\hline $\begin{array}{l}\left(\mathrm{NH}_{4}\right)_{2} \mathrm{SO}_{4} \\
\text { precipitation, } \\
\text { dialyzed }\end{array}$ & 15482 & 1500 & 10.32 & 1.32 & 75.75 \\
\hline
\end{tabular}

After the isolation, identification of isolates and screening of protease production, the significant protease producer isolates were used for sequencing. The isolates which have 
protease enzyme producing activity were selected for confirm identification. These isolates were initially identified by Ribosomal Database Project (RDP). By sequencing these isolates were confirmed as Bacillus species and excellent protease producer strain Bacillus cereus (SP3) was used for extraction and partial purification purpose.

The isolated source of Bacillus cereus (SP3) has maximum protease enzyme production was observed at $72 \mathrm{~h}$. The protease enzyme from Bacillus SP3 was partially purified by ammonium sulphate fractionation. One liter of the bacterial broth was centrifuged at $10000 \mathrm{rpm}$ for $10 \mathrm{~min}$ at $4^{\circ} \mathrm{C}$. The specific activity of crude protease enzyme was $7.71 \mathrm{U} / \mathrm{mg}$ of protein. The specific activity of ammonium sulphate fractionation is found to be 10.32 and the fractionation is 1.32 fold purified from the crude enzyme preparation yielding $75.75 \%$ from the crude protein.

The optimum $\mathrm{pH}$ of protease produced from Bacillus cereus (SP3) shown at the $\mathrm{pH} 7.0$. The purified enzyme was loaded onto holes punched on skim milk agar. After 24-48 hours of incubation it was observed that clear zones were formed successfully. Other investors, reported that both Bacillus anthracis, S-44 and Bacillus cereus var. mycoides, S-98 exhibited their maximum ability to biosynthesize proteases within $24 \mathrm{~h}$ incubation period since the productivity reached up to 126.09 units/ml for Bacillus anthracis, S-44 corresponding to 240.45 units/ml for Bacillus cereus var. mycoides, S98 respectively. Moreover, Johnvesly et al., (2002) found that a high level of extracellular thermostable protease activity was observed after $24 \mathrm{~h}$ incubation and hence our results are in complete accordance with earlier reports. Other investigators recorded optimum proteolytic activity at different $\mathrm{pH}$ values such as pH 7.8 (Tsujibo et al., 1990), 8.0 (Anwar and Saleemuddin, 1997), 9.8-10.2
(Kumar et al., 1999) and 12-13 (Takami et al., 1989).

In conclusion, the isolated new source of protease producing bacteria from the soil sample of dairy industry and partially purified protease may be alternative source and also used for the potential industrial applications. Although many potent strains are on market for enzyme production, scientists prefer studying on new isolates because they could be alternative for commercial use. This is very cheap source to enhance the Protease production and recommended that isolated potential protease producer can be used in various industries.

\section{References}

Aleksieva, P. and Peeva, L. 2000. Investigation of acid protinase biosynthesis by the fungus Humicola Lutea 120-5 in an airlift bioreactor. Enzyme Microb. Technol., 26: 402-405.

Anwar, A., Saleemudin, M. 2000. Alkaline protease from spilosoma oblique: potential application in bioformulation. Biotechnol. Appl. Biochem., 31(2): 85-89.

Anwar, A. and Saleemuddin, M. 1997. Biotech. App. Biochem., 25: 43-46.

Banik, R.M., Prakash, M. 2004. Laundry detergent compatibility of the alkaline protease from Bacillus cereus. Microbiol. Res., 159: 135-140.

Beg, K.B., Sahai, V., Gupta, R. 2003. Statistical media optimization and alkaline protease production from Bacillus mojavensis in a bioreactor. Process Biochem., 39: 20032009.

Brown, E.D. and Yada, R.Y. 1991. Spin-labelling and differential scanning colorimetry study of the denaturation of aspartic pectinases from the fungi Endhatia parasitica and Mucor. Miehei. Agric. Biol. Chem., 55: 1639-1641.

Escobar, J. and Barnett, S.M. 1993. Effect of agitation speed on the synthesis of Mucor miehei acid protease. Enzyme Microb. Technol., 15: 1009-1013. 
Geethanjali, S. and A. Subash. 2011. Optimization of protease production by Bacillus subtilis isolated from mid gut of fresh water fish Labeo rohita. World J. Fish Mar. Sci., 3: 88-95.

Gerze, A. Omay, D. and Guvenilir, Y. 2005. Partial purification and characterization of protease enzyme from Bacillus subtilis and Bacillus megatherium. Appl. Biochem. Biotechnol., 121-124: 335-45.

Gupta, R., Beg, Q.K., Lorenz, P. 2002. Bacterial alkaline proteases: molecular approaches and industrial applications. Appl. Microbiol. Biotechnol., 59(1): 15-32.

Gupta, R., Gupta, N., Rathi, P. 2004. Bacterial Proteases: an overview of production, purification and biochemical properties. Appl. Microbiol. Biotechnol., 64(6): 76381.

Haq, I.U., Mukhtar, H. and Umber, H. 2006. Production of protease by Penicillium chrysogenum through optimization of environmental conditions. J. Agri. Social Sci., 2(1): 23-25.

Horikoshi, K. 1971. Alkaline protease production by Bacillus No. 221. Agric. Biol. Chem., 35(9): 1407-1414.

Ishikawa, H., Ishimi, K., Sugiura, M., Sowa, A. and Fujiwara, N. 1993. Kinetics and mechanism of enzymatic hydrolysis of gelatin layers of X-ray film and release of silver particles. J. Fermentation and Bioengi., 76(4): 300-305.

Johnvesly, B., Manjunath, B.R. and Naik, G.R. 2002. Pigeon pea waste as a novel, inexpensive, substrate for production of a thermostable alkaline protease from thermoalkalophilic Bacillus sp. JB-99. Biores. Technol., 82: 61-64.

Kumar, C.G., Tiwari, M.P., Jany, K.D. 1999. Novel alkaline serine proteases from alkalophilic Bacillus spp.: purification and some properties. Proc. Biochem., 34: 441449.
Mahajan, R.T. and Badgujar, S.B. 2010. Biological aspects of proteolytic enzymes: A Review, J. Pharm. Res., 3(9): 2048-2068.

Nout, M.J.R. and Rombouts, F.M. 1990. Recent developments in temple research. J. App. Bacterial., 69: 609-633.

Padmapriya Balakrishnan, T., Rajeswari, R., Nanditaand, F., Raj. 2012. Production and Purification of Alkaline Serine Protease from Marine Bacillus sp and its Application in Detergent Industry. European J. Appl. Sci., Vol 4(1): 21-26.

Raju, K., R. Jaya and C. Ayyanna. 1994. Hydrolysis of casein by bajara protease importance. Biotechnol. Coming Decadea, 181: $55-70$

Salem, S.R., Shabed, M.S.A., Amara, A.A. 2009. Optimization of Thermophilic Protease Production in Bacillus Mixed Cultures under Mesophilic Conditions. World $J$. Agri. Sci., 5(3): 375-383.

Sjodahl, J., Emmer, A., Vincent, J. and Roeraade, J. 2002. Characterization of proteinases from Antarctic krill. Euphausia superba. Protein Expression and Purification, 26: 153-161.

Soares, V.F., Castilho, L.R., Bon, E.P. and Freire, D.M. 2005. High-yield Bacillus subtilis protease production by solid-state fermentation. Appl. Biochem. Biotechnol., 121-124: 311-9.

Takami, H., Akiba, T. and Hprikoshi, K. 1989. Production of extrsp. AH-101. Appl. Microbiol. Biotechnol., 30: 120-124.

Tsujibo, H., Miyamoto, K., Hasegawa, T. and Inamori, Y. 1990. Purification and characterization of two types of alkaline serine proteases produced by an alkalophilic Actinomycete. J. App. Bacteriol., 69: 520-529.

Wiseman, A. 1987. Handbook of Enzyme Biotechnology, second ed., John Wiley Sons, New York, EUA.

\section{How to cite this article:}

Patil, R.C. and Jadhav, B.L. 2017. Isolation and Characterization of Protease Producing Bacillus Species from Soil of Dairy Industry. Int.J.Curr.Microbiol.App.Sci. 6(6): 853-860. doi: https://doi.org/10.20546/ijcmas.2017.606.100 